\title{
Effect of Self-Concept, Reference Group, Online Shop Social Media, and Lifestyle on Consumptive Behavior of Students
}

\author{
Nofriansyah $^{1}$, Marwan ${ }^{2}$ \\ 1Universitas Negeri Padang, Padang, Indonesia, $\square$ nofriansyah10@gmail.com \\ 2Universitas Negeri Padang, Padang, Indonesia, $\square$ marwan@fe.unp.ac.id
}

\begin{abstract}
This study aims to determine the effect of Self-Concept, Reference Group, Online Shop Social Media and Lifestyle On Consumptive behavior Student of Padang State University Faculty of Economics. The population in this study were all FE students UNP. The sampling technique used was accidental sampling in order to obtain a sample of 396 students. The research instrument used in the form of a questionnaire. Analysis of the data in this study using Path Analysis (Path Analysis) using SPSS 16.0 for Windows.The results showed that: (1) the selfconcept affects the lifestyle, (2) the reference group does not affect the lifestyle, (3) online shop social media influence on lifestyle, (4) the concept of self-influence on consumer behavior, ( 5) reference group has no effect on consumer behavior, (6) online shop social media has no effect on consumptive behavior, and (7) the lifestyle influence consumptive behavior.
\end{abstract}

Keywords: self-concept, the reference group, online shop social media, lifestyle, consumptive behavior.

\section{Introduction}

Adolescence is a period of transition and a search for identity, adolescents undergo a process of formation in their behavior, where teenagers seek and strive to achieve the pattern of the ideal self, it causes the teens is easy to be tempted by promotions of products and services offered in a number of mass media or directly promoted in the market. Increasing number of teens who have excessive consumption behavior and feared if it continues will be a pattern or hedonistic lifestyle. Consumption behavior is an act of individuals in obtaining and using goods or services through a specific decision making process in an effort to meet the needs in order to reach maximum satisfaction (Hartiyani 2016), Every individual who is always in need of goods and services in fulfilling the needs and desires of the infinite is what makes one of the problems that led to the behavior of individuals into consumer behavior with free lifestyle.

The phenomenon of consumer behavior occurred in the country of Indonesia. Indonesia is one country that has a very high consumer behavior. Indonesia is ranked the world's 11 consumer behavior (Grover 2011), 93\% of Indonesian consumers including recreational shoppers (recreational shopper) they shop not out of necessity, but more for the pleasure (Damayanti \& Nu'man, 2007). One of the actors in the Indonesian consumer behavior by students. Students are a group of consumeroriented person, because this group likes to try new things and branded, students will tend to imitate the new fashions. (Damayanti \& Nu'man, 2007).

Based on the results of preliminary observations made on the campus of the State University of Padang, obtained information that a lot of students who exceed the limit in the consumption of goods or services. It is known that of the 25 students in the average has $71 \%$ of students do consumer behavior and $29 \%$ of students do not do the consumer behavior.

Based on the results of interviews with some of the students that almost all the students interviewed said often can't management time well, because more fun to access social media, then forget the time when going to the mall for just a walk or shopping, hang out in the café with her friends, go where entertainment, cinema etc.

Consumptive behavior that occurs in various places one of Indonesia are caused by external factors and internal factors. Internal factors that influence consumer behavior is the concept of self. 
Prime (2017) which says that the internal factors that influence consumer behavior is observation, selfconcept, learning, motivation, personality and self-esteem. While external factors that lead to consumer behavior is the reference group. According to Lin and Chen (2009) reference group is able to contribute to the changes that occur in the variable behavior of consumption by $52 \%$. This shows that people still can't control the consumptive behavior well as the negative influence of the reference group.

While other internal factors that influence consumer behavior is a lifestyle. Lifestyle also gives an influence on consumer behavior patterns of students. The higher a person's lifestyle, the higher the person's consumption behavior (Kaharu and Budiarti 2016), Lifestyle is a behavior that is characterized by a life of luxury and excessive (Fitria 2015), If that continues to be done and not thinking owned financial form, while the excessive desire, it can cause negative effects to society. If finances are insufficient desire anything could be done just to make it happen, for example, rob, steal, and so on. Illustration lifestyle is expected that students learn good lifestyle, which is good for the future-oriented so useful in the future for the country and nation. Students are not affected by the outside world, remained focused on his college campus. Consumer behavior like this can always be rooted in the lifestyle of students. Thus, in its development, people will grow up to be people with consumptive lifestyle. Consumptive lifestyles should be supported with adequate financial. Greater problem occurs when the level of financial achievement was made with all sorts of ways that are not healthy. Start of work patterns that to use various instant ways such as corruption. In the end the consumer behavior will cause some impact on both economic and psychological.

Psychological impact, a person will feel themselves inferior to others if he could not buy what she wants. While socially, someone will always follow the attributes that are favored without going be your self. Because you want to buy something they want, regardless of how much money should be spent, someone will keep on asking parents somehow regardless of ethics again. By doing so, they will see their parents as a money machine that will give them money whenever they ask.

While other external factors, namely the online shop on social media. Several types of online social media shop most practiced is an online shop instagram, twitter, facebook and whatsapp. These days social media is one medium of communication and information that is widely used by most people. Social media can access information and communicate in a flexible, fast, and economical without limitation of time and place. Through social media, human any time can find and share information in everyday life, even one like instagram social media is appropriate as live as any gallery can be poured therein. Users of social media such as: instagram each month more than 800 million an even every day to reach 500 million people. Social media is a smartphone-based applications from online to share photos, (Paulina Guerrero, et al 2016), Shop online shopping phenomenon in social media such as: instagram, whatsapp, twitter, and facebook has spread in various Indonesian society, both parents, adults, to teenagers. Online shop or online shopping is a process of purchase of goods or services made over the internet (Miranda et al. 2017), Shop online presence makes the process of buying and selling to be more modest, but it is the marketing of products made by the seller on social media websites make people (buyers) resulted in two convictions: save time and cost (Lubis and North 2018).

\section{Methods}

This type of research is descriptive and associative. This research was conducted at the Faculty of Economics, University of Padang in December 2018. The entire population in this study Faculty of Economics University of Padang. Accidental sampling technique that sampling obtained a total sample of 396 students.

The data collection technique using questionnaires / questionnaire has been in testing the validity and reliability testing. Data were analyzed using descriptive analysis and path analysis. The steps path analysis: data normality test, homogeneity test data, and test path coefficient. Path coefficient test is divided into two sub-structures, namely, sub-structure 1 (the influence of self-concept, the reference group, online media shop sosiaal against lifestyle). 


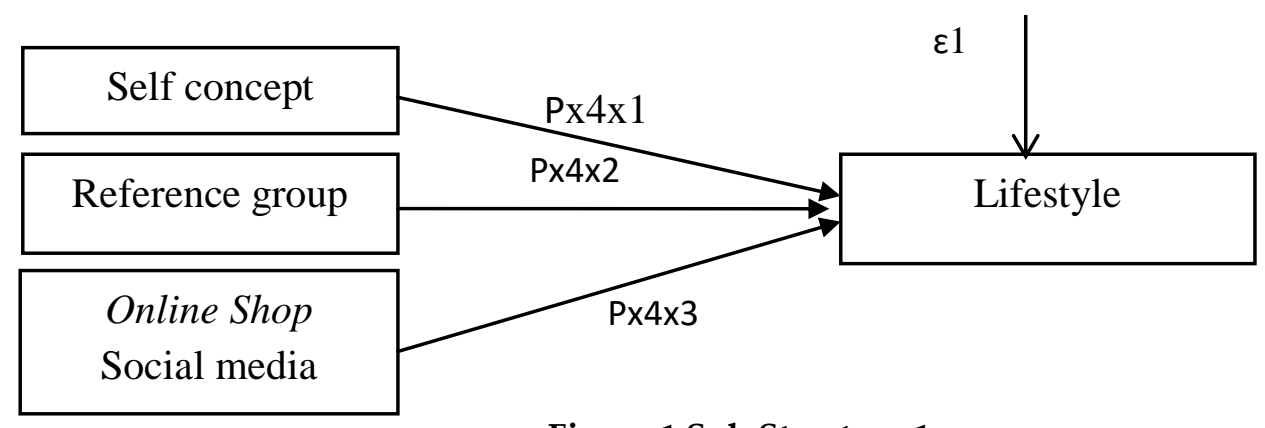

Figure 1 Sub Structure 1

With the structure of this equation:

$X_{4}=P_{X 4 . X 1} X_{1}+P_{X 4 . X 2} X_{2}+P_{X 4 . X 3} X_{3}+\varepsilon_{1}$

and the sub-structure 2 (the effect of self-concept, the reference group, online shop social media, and lifestyle of the consumer behavior)

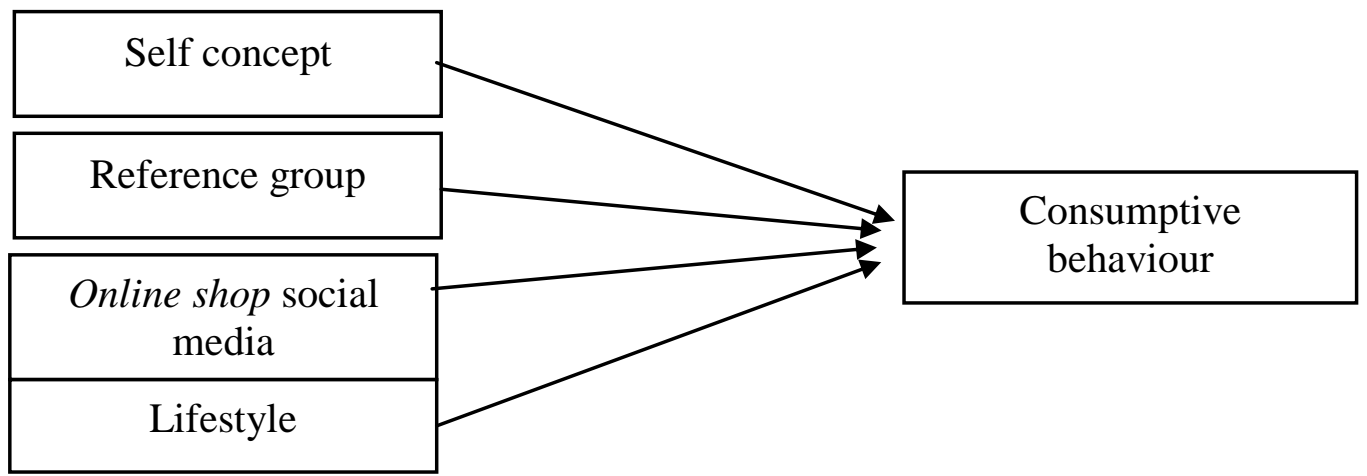

Figure 2 Sub Structure 2

With the structure of this equation:

$\mathrm{Y}=\mathrm{Pyx}_{1} \mathrm{X}_{1}+\mathrm{Pyx}_{2} \mathrm{X}_{2}+\mathrm{Pyx}_{3} \mathrm{X}_{3}+\mathrm{Pyx}_{4} \mathrm{X}_{4}+\varepsilon_{2}$

Hypothesis testing using t test to test the path coefficients and determine the level of significance of each independent variable on the dependent variable under the condition :

1) If $\mathrm{t} t \mathrm{table}$, then Ho is rejected means that there is a significant relationship between independent variables with the dependent variable $\geq$

2) If $t<t$ table, then Ho accepted means there is no relationship between independent variables and related variables

Then determine the coefficient of the line, the amount of direct and indirect influence of the independent variables to the dependent variable.

\section{Results and Discussion}

Results

This study to see the effect of self-concept, the reference group, online shop social media, and lifestyle of the consumer behavior of students.

Based on the results of the research data processing using the program SPSS for Windows version 16. The results obtained test path coefficients in the table that will show the following: 
Table 1 Coefficient Line Self-Concept, Reference Group, Social Media and Online Shop Of Lifestyle Students

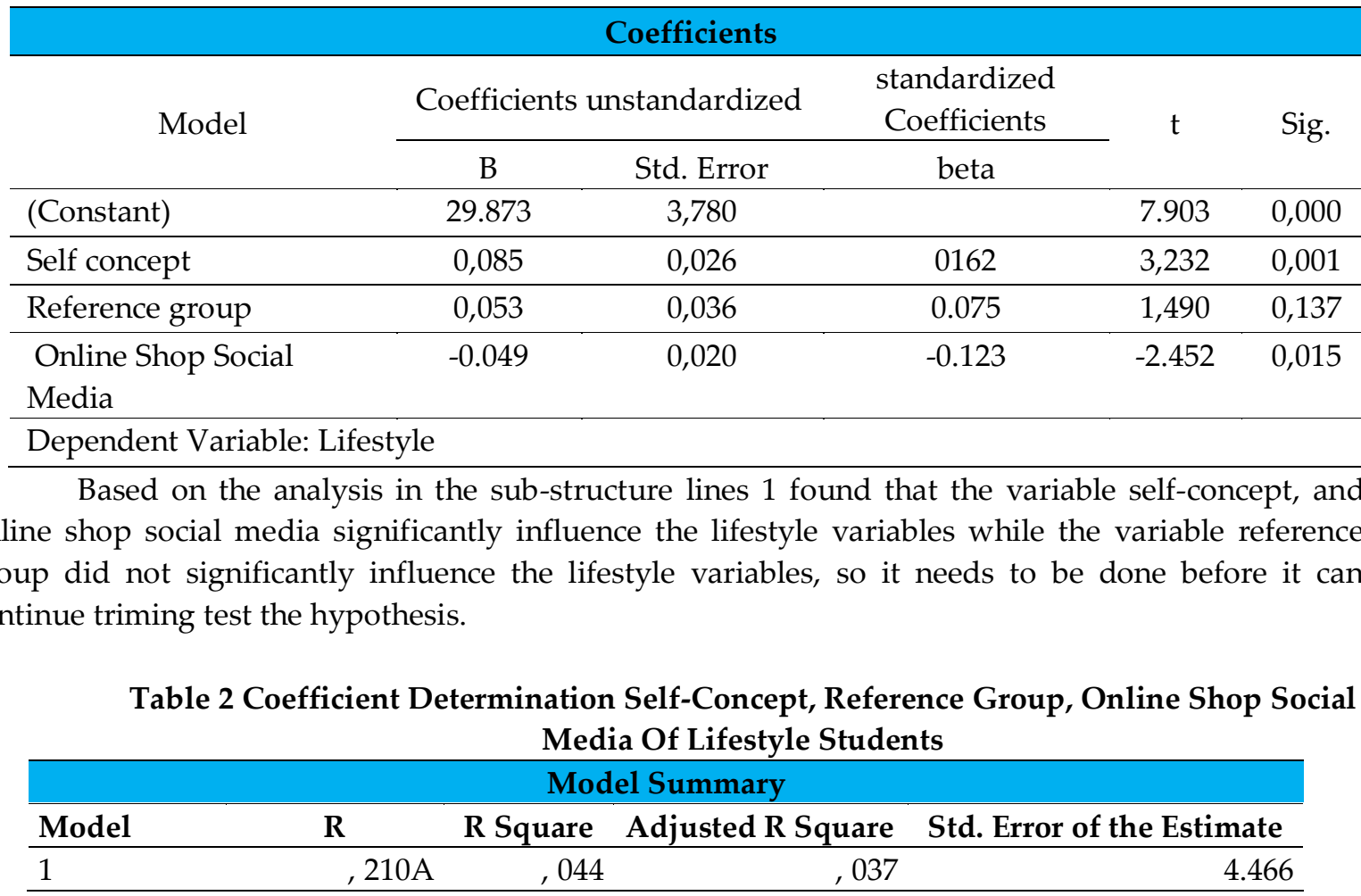

The influence of other variables that can be seen from the value of the coefficient of residual (Px4ع1) can be calculated as follows:

$$
\begin{aligned}
\text { Px4\&1 } & =\sqrt{1-R^{2} \times 1 \times 2 \times 3 \times 4} \\
& =\sqrt{1-0,044} \\
& =\sqrt{0,956} \\
& =0.977
\end{aligned}
$$

Then if the effect is not significant variables excluded from the model, it can be made triming test

\begin{tabular}{|c|c|c|c|c|c|}
\hline \multicolumn{6}{|c|}{ Coefficients } \\
\hline \multirow{2}{*}{ Model } & \multicolumn{2}{|c|}{ Coefficients unstandardized } & \multirow{2}{*}{$\begin{array}{c}\begin{array}{c}\text { standardized } \\
\text { Coefficients }\end{array} \\
\text { beta } \\
\end{array}$} & \multirow[t]{2}{*}{$\mathbf{t}$} & \multirow{2}{*}{ Sig. } \\
\hline & B & Std. Error & & & \\
\hline (Constant) & 33.025 & 3.137 & & 10.527 & 0,000 \\
\hline Self concept & 0.079 & 0,026 & 0.151 & 3,037 & 0,003 \\
\hline $\begin{array}{l}\text { online Shop } \\
\text { Social media }\end{array}$ & -0.045 & 0,020 & -0.112 & 3,609 & 0,025 \\
\hline Dependent V & Style coh & & & & \\
\hline
\end{tabular}
in the following table:

Table 3 Path coefficient danOnline Shop Self Concept Social Media Against Student Lifestyle (Reference Group issued)

According to the table 25 after triming test, a decline on the path coefficient of 0.162 variable selfconcept becomes 0.151 . While the variable shop online social media was also a decline from the path 
coefficient becomes $-0.112-0.123$. The images of the sub structure 1 after a variable reference group removed, can be described as follows:

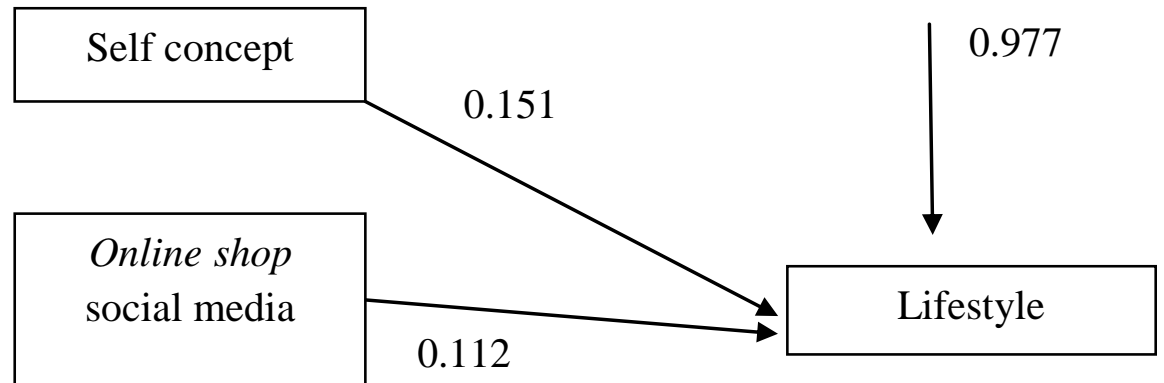

Figure 3 Sub Structure 1 (Effects of Self-Concept and Social Media Online Shop Of Lifestyle Students)

Based on the above sub-structure, we can make the following equation:

$X_{4}=P_{X 4 . X 1} X_{1}+P_{X 4 . X 2} X_{3}+\varepsilon_{1}$

$X_{4}=0,151 X_{1}+0,112+0,977 \varepsilon_{1}$

Sub Structure 2 (Influence of Self-Concept, Reference Group, Online Shop Social Media and Lifestyle Students Against Consumer Behavior).

Table 4 Coefficient Line Self-Concept, Reference Group, Online Shop Social Media and Lifestyle Consumer Behavior Against Students

\begin{tabular}{|c|c|c|c|c|c|}
\hline \multicolumn{6}{|c|}{ Coefficients } \\
\hline \multirow{2}{*}{ Model } & \multicolumn{2}{|c|}{$\begin{array}{c}\text { Coefficients } \\
\text { unstandardized }\end{array}$} & \multirow{2}{*}{$\begin{array}{c}\text { standardized } \\
\text { Coefficients }\end{array}$} & \multirow[t]{2}{*}{$\mathbf{t}$} & \multirow{2}{*}{ Sig. } \\
\hline & B & Std. Error & & & \\
\hline (Constant) & 15.924 & 5,918 & & 2.691 & 0.007 \\
\hline Self concept & .298 & 0,039 & 0.359 & 7.642 & 0,000 \\
\hline Reference group & .130 & 0.052 & 0,118 & 2.513 & 0,012 \\
\hline $\begin{array}{l}\text { Online shop social } \\
\text { media }\end{array}$ & 0,072 & 0,029 & 0,115 & 2,456 & 0,014 \\
\hline Lifestyle & 0.275 & 0.073 & 0.175 & 5.647 & 0,000 \\
\hline
\end{tabular}

Based on the analysis in the sub-structure paths 2 that the variable self-concept, the reference group, shop online social media, and lifestyle variables significantly influence consumer behavior.

To see the size of the contribution or other variables path coefficients as follows:

Table 5 Coefficient Determination Self-Concept, Reference Group, Online Shop Social Media and Lifestyle Consumer Behavior Against Students

\begin{tabular}{llrrr}
\multicolumn{4}{c}{ Model Summary } \\
\hline Model & $\mathrm{R}$ & R Square & Adjusted R Square & Std. Error of the Estimate \\
\hline 1 &, $430 \mathrm{a}$ &, 185 &, 177 & 6.494 \\
\hline
\end{tabular}

The influence of other variables that can be seen from the value of the coefficient of residual (Pye2) can be calculated as follows:

Py\&2 $=\sqrt{1-R^{2} \times 1 \times 2 \times 3 \times 4}$

$=\sqrt{1-0,185}$

$=\sqrt{0,815}$

$=.902$ 
The images of sub-structure 2 as follows:

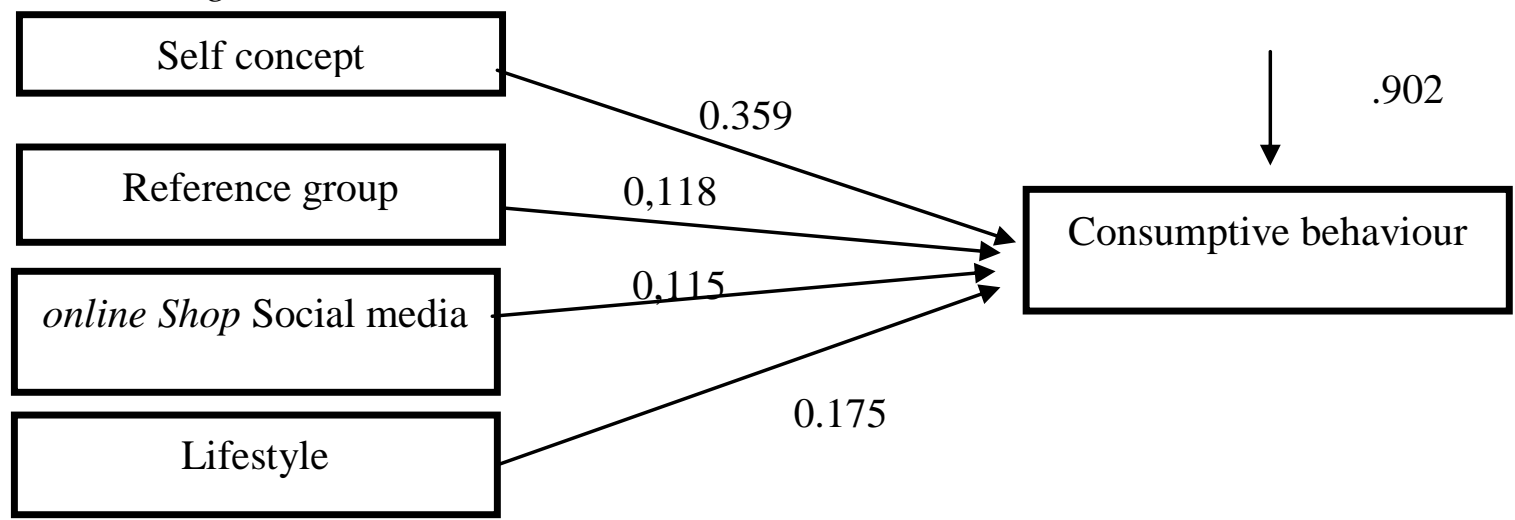

Figure 3 Sub Structure 2 (Influence of Self-Concept, Reference Group, Online Shop Social Media and Lifestyle Students Against Consumer Behavior)

Based on the above sub-structure, we can make the following equation:

$\mathrm{Y}=P_{Y . X 1} X_{1}+P_{Y . X 2} X_{2}+P_{Y . X 3} X_{3}+P_{Y . X 4} X_{4}+\varepsilon_{2}$ $\mathrm{Y}=0,359 \mathrm{X} 1+0,118 \mathrm{X} 2+0,115 \mathrm{X} 3+0,175 \mathrm{X} 40.902+\varepsilon_{2}$

From the data processing of the above can be formulated path structure and the influence of independent variables on the dependent variable in the following figure:

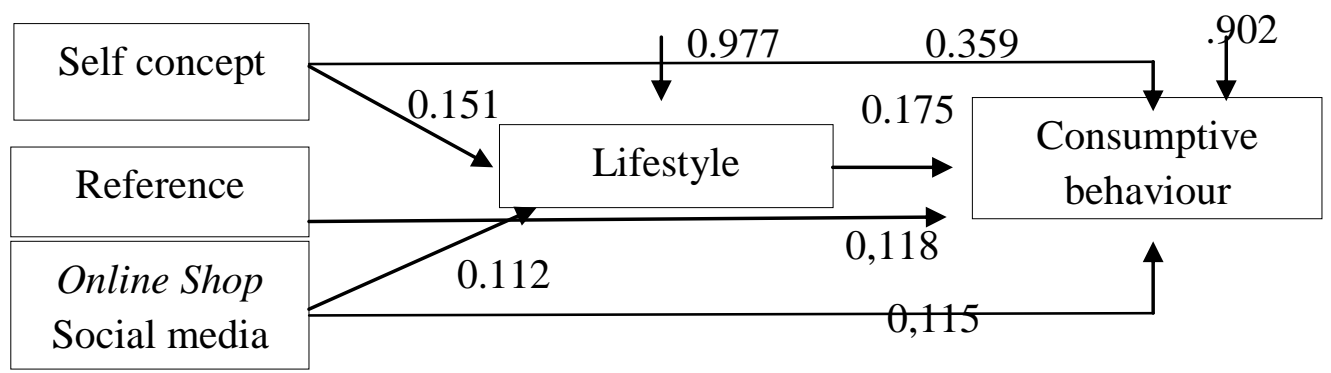

Figure 4 Structure of End of Line

\section{Determining the Effect of Variable}

Direct Impact

1) The direct effect of self-concept $(\mathrm{X} 1)$ on consumer behavior $(\mathrm{Y})$

$\mathrm{X} 1 \mathrm{Y}$ to $\mathrm{Y}=\mathrm{X} 1 \leftarrow \mathrm{X} 1 \rightarrow$

$$
\begin{aligned}
& =(\operatorname{Pyx} 1)(\operatorname{Pyx} 1) \\
& =(0.359)(0.359) \\
& =0.129
\end{aligned}
$$

So the magnitude of the direct influence of the self-concept (X1) to the consumer behavior of students $(\mathrm{Y})$ is $12.9 \%$.

2) The direct effect of the reference group (X2) to the consumer behavior of students $(Y)$

$\mathrm{X} 2 \mathrm{Y}$ to $\mathrm{Y}=\mathrm{X} 2 \leftarrow \mathrm{X} 2 \rightarrow$

$$
\begin{aligned}
& =(\text { Pyx2) }(\text { Pyx2 }) \\
& =(0.118)(0.118) \\
& =0.013924
\end{aligned}
$$

So the magnitude of the direct influence of the reference group (X2) to the consumer behavior of students $(\mathrm{Y})$ is approximately $1.39 \%$.

3) The direct effect of online shop social media (X3) against $(Y)$ of the consumer behavior of students $(\mathrm{Y})$

$$
\begin{array}{rl}
\mathrm{X} 3 \text { to } \mathrm{Y}=\mathrm{Y} X 3 & \mathrm{X} 3 \longrightarrow \\
=(\mathrm{Pyx} 3)(\mathrm{Py} 33)
\end{array}
$$




$$
\begin{aligned}
& =(0.115)(0.115) \\
& =0.013225
\end{aligned}
$$

So the magnitude of the direct influence of online shop social media (X3) on consumer behavior $(\mathrm{Y})$ is $1.32 \%$.

4) The direct effect of lifestyle (X4) on consumer behavior (Y)

$\mathrm{X} 4 \mathrm{Y}$ to $\mathrm{Y}=\mathrm{X} 4$

$$
\begin{aligned}
& =(\text { Pyx4) }(\text { Pyx4 }) \\
& =(0.175)(0.175) \\
& =0.030625
\end{aligned}
$$

So the magnitude of the direct influence of lifestyle (X4) on consumer behavior $(\mathrm{Y})$ is equal to $3.0625 \%$

\section{Indirect Influence}

1) The indirect effect of self-concept (X1) on consumer behavior (Y) through lifestyle (X4). $\mathrm{X} 1$ to $\mathrm{Y}$ via:

$$
\begin{aligned}
\mathrm{X} 4 \Omega & \Omega \mathrm{X} 4 \mathrm{X} 1=\mathrm{Y} \leftarrow \mathrm{Y} \longrightarrow \\
& =(\mathrm{PYX} 1)(\mathrm{rx} 1 \times 4)(\mathrm{Pyx} 4) \\
& =(0.359)(0.0352)(0.175) \\
& =0.00221
\end{aligned}
$$

So the indirect effect of self-concept to consumer behavior through lifestyle by $0.22 \%$

2) The indirect effect of reference group (X2) on consumer behavior (Y) through lifestyle (X4).

$\mathrm{X} 2$ to $\mathrm{Y}$ via:

$$
\begin{array}{rl}
\Omega X 4 & X 4 X 2=\mathrm{Y} \leftarrow \mathrm{Y} \longrightarrow \\
& =(\mathrm{PYX} 2)(\mathrm{rx} 2 \times 4)(\mathrm{Pyx} 4) \\
& =(0.118)(0.0153)(0.175) \\
& =0.0003
\end{array}
$$

So the indirect influence of the reference group on consumer behavior through lifestyle is $0.31 \%$

3) The indirect effect of online shop social media (X3) On Consumer Behavior (Y) Through Lifestyle $(X 4)$

$\mathrm{X} 3$ to $\mathrm{Y}$ via:

$$
\begin{aligned}
& \Omega X 4 X 4 X 3=\mathrm{Y} \leftarrow \mathrm{Y} \longrightarrow \\
& =(\mathrm{PYX} 3)(\mathrm{rX3x4})(\mathrm{Pyx} 4) \\
& =(0.115)(0.085)(0.175) \\
& =0.0017
\end{aligned}
$$

So the indirect effect of social media to online shop consumer behavior through lifestyle is $0.17 \%$. 
Table 6

Recapitulation Effect Againt Independent Variable Dependent

\begin{tabular}{|c|c|c|c|}
\hline Num. & Causal Relationships & $\begin{array}{l}\text { large Influence } \\
(\%)\end{array}$ & $\begin{array}{l}\text { total Effect } \\
(\%)\end{array}$ \\
\hline 1 & $\begin{array}{l}\text { The influence of the self-concept of the consumer } \\
\text { behavior }\end{array}$ & 12.9 & \\
\hline 2 & $\begin{array}{l}\text { The influence of the reference group on consumer } \\
\text { behavior }\end{array}$ & 1.39 & \\
\hline 3 & $\begin{array}{l}\text { The influence online shop social media on } \\
\text { consumer behavior }\end{array}$ & 1.32 & \\
\hline 4 & The influence of lifestyle on consumer behavior & 3.06 & \\
\hline & Total Direct Impact & & 18.67 \\
\hline 5 & $\begin{array}{l}\text { The indirect effect of self-concept to consumer } \\
\text { behavior through lifestyle }\end{array}$ & 0.22 & \\
\hline 6 & $\begin{array}{l}\text { Indirect influence of the reference group on } \\
\text { consumer behavior through lifestyle }\end{array}$ & 0.31 & \\
\hline 7 & $\begin{array}{l}\text { Online shop indirect effect of social media on } \\
\text { consumer behavior through lifestyle }\end{array}$ & 0.17 & \\
\hline & $\begin{array}{c}\text { Total Indirect Influence } \\
\end{array}$ & & 0.70 \\
\hline Total I & ffect of Direct and Indirect & & 19.37 \\
\hline Influe & ce of Other Variables & & 80.63 \\
\hline
\end{tabular}

Based on the above table it can be seen the influence of each independent variable on the dependent variable, either directly or indirectly. Total donated influence of independent variables on the dependent variable of $19.37 \%$ while $80.63 \%$ was contributed by other variables that are not included in this study.

\section{Discussion}

Based on the results of data processing showed the following results:

\section{Effect of Self Concept of the Faculty of Economic Lifestyle Padang State University}

Based on the analysis path that has been done, hypothesis test showed that self-concept and a significant positive effect on student life style. This study proves that the concept of self can contribute in one's lifestyle. The better the self-concept, then students will increasingly have a good lifestyle, and conversely, if the bad concept itself then the student will have a bad lifestyle.

The results of this study showed that self-concept is one of the internal factors are important, because the concept itself determines how the lifestyle of students in everyday life. The concept itself is the notion of the individual, of how individuals see themselves as a person, how people feel about themselves, and how the individual wants himself to be human that is expected(Roe and Bruwer 2017).

Based on test data variables description in mind that the concept of self has enough categories .It means that students of the Faculty of Economics University of Padang has a self-concept of being. Therefore, students should improve their self concept in order to adapt to the possibilities of unexpected and improving himself in adjusting in modern lifestyle today.

The results are consistent with the results of research conducted by Pontania (2016) and Boyd Thomas and Lee Okleshen Peters (2009) which revealed that self-concept and a significant positive effect on lifestyle. 


\section{Style of Reference Group of the Faculty of Economics, University of Padang.}

Based on the analysis path models, there is no significant effect on the variable reference group against the lifestyle of students. It means the absence of a reference group contribution in student life. According to Edward (2013) the reference group for someone can consist of one or more persons and usually the reference group could be something real (a real person) or that are not real and symbolic (eg the successful executive or celebrity success: political figures, actors and sportsmen ).

The results of this study contrast with the results of research Salazar, et al (2013) that said reference if have a significant impact on a person's lifestyle. Another study conducted by Syahfitri (2017) also said that there is a direct influence of the reference group against the lifestyle of the city of Pekan baru.

\section{Online Shop Social Media Influence on Lifestyle Students of Faculty of Economics, University of Padang}

Based on the analysis path that has been done, that online shop media social and a significant positive effect on the lifestyle of students Faculty of Economics, University of Padang. This means that their contribution online shop social media in the lifestyle of students of Faculty of Economics, University of Padang.

Based on test data variable descriptions online shop is known that social media has a considerable category .It means that students of the Faculty of Economics Universitas Negeri Padang in online shopping in the category that are still at the limits of reasonableness.

The results are consistent with the results of research conducted by Pandey and Chawla (2014)online shop say that the effect on a person's lifestyle. In addition, another study conducted by Way, et al (2016) which says that the online shop (online shopping) can alter one's lifestyle in an instant. This means that the online shop social media significantly influence the lifestyle of students Faculty of Economics, University of Padang. Where the majority of people or students in this study agree with the stigma that the reason to online shop in social media is cheaper, more practical, contemporary product, and do not need to leave home.

\section{Influence Consumer Behavior Self Concept of the Faculty of Economics University of Padang}

Based on the results of the path model analysis has been done, hypothesis testing showed that selfconcept and a significant positive effect on consumer students. This means that a good or bad selfconcept that you have will determine the level of consumer behavior of students. This study proves that consumer behavior is motivated by the concept of self-possessed by each of the individual self. This is in line with research conducted by Mittal (2015) who say that the more a person has low selfconcept, the higher the higher behavior consumption and self-concept that a person has, the lower its consumption behavior.

The results of this study indicate that self-concept is one of the most important internal factor, because the concept itself determine how attitudes, traits, and behaviors of students consumption. The results are consistent with the results of the study Hidayat and Kurniawan (2016) who says that the concept of self-influence on consumer behavior. In addition, it is also consistent with the results found by the Murwanti (2015) that consumer behavior is influenced by the concept of self, it is increasingly evident that someone who has a strong self-concept, the more there is a tendency consumptive behavior also increased,

\section{Reference Group Influence on Consumer Behavior Faculty of Economics University of Padang}

Based on the analysis path models, there is no significant effect on the variable reference group on consumer behavior of students. It has been suggested that the absence of a reference group contribution in the consumer behavior of students. The tendency of individuals to behave excessively in to buy something irrational and placing the needs but put forward his wishes(Thomas 2015), If the consumer behavior continue to occur will result in financial conditions become uncontrollable 
otherwise it will lead to over-extraction and result in a buildup of goods because of purchases made redundant or continuously (Astuti 2013),

The results of this study contrasts with research conducted by Rusich (2008) which says that the reference group has a strong influence on consumer behavior because it is a place for people to do the comparison value, providing information and guidance in making consumption.

\section{Online Shop Social Media Influence on Consumer Behavior of Students of Faculty of Economics, University of Padang}

Based on the analysis path models, there is no significant influence on the variables online shop social media on consumer behavior of students. It has been suggested that the absence of contributions online shop social media on consumer behavior research to students of the Faculty of Economics University of Padang.

The results are consistent with the results of research conducted by Kamelia (2007) which revealed that there is no influence on the online shop social media on consumer behavior instagram students of Communication Studies, State University of Malang.

The results of this study contrast with the results of research Wibowo (2018) which says that the online shop positive and significant impact on consumer behavior. The rapid development of the Internet makes a person has a good innovation in spending their products through social media, so that their online shop social media affects someone to behave consumptive (Stephen 2008).

\section{Lifestyle Influence on Consumer Behavior of Students of Faculty of Economics, University of Padang}

Based on the analysis path models, there is significant influence on lifestyle variables on consumer behavior of students. May mean that the contribution of lifestyle in the consumer behavior of students. The results showed that a sedentary lifestyle is one of the internal factors are important, because of the lifestyle determine how the actions of students in consumer behavior. If the student has a high lifestyle, then the consumer behavior will also be higher. Vice versa, if the student lowered his lifestyle then correspondingly reduced consumptive behavior patterns. Lifestyle is a part of everyday social life of people in the modern world (Liang 2014),

Based on test data description of the variables known that lifestyle variables students were in good enough category. This means that students have a lifestyle that was so that his lifestyle is still in the category of reasonable limits. The results are consistent with the results of research conducted by Angra Melina (2018) which revealed that a sedentary lifestyle significantly influence consumer behavior of students. Lifestyle shows how the consumption patterns that reflect or describe individuals spend time and money (Sukarno, et al 2017).

\section{Conclusion}

Based on the results of processing and discussion of this research resulted in the following conclusions:

1. The self-concept has an influence on lifestyle. Forms of self-concept variables influence on the lifestyle is positive. This shows that the better the concept itself, it will be better the lifestyle of students of Faculty of Economics, University of Padang.

2. Reference group does not have an influence on lifestyle. This shows that there is no reference group contribute more to the lifestyle of students Faculty of Economics, University of Padang.

3. Online shop social media has an influence on lifestyle. Form of variables influence social media to online shop is a positive lifestyle. This research will contribute to the development of knowledge to the public regarding knowledge regarding the online purchasing process. besides that it can also be taken into consideration by individuals to do business through digital.

4. The self-concept has an influence on consumer behavior. Forms of self-concept variables influence on consumer behavior is positive. This suggests that a good or bad self-concept that 
you have will determine the level of consumer behavior Faculty of Economics University of Padang.

5. Reference group does not have an influence on consumer behavior. This suggests that the absence of a reference group contribution of this research to consumer behavior students of Faculty of Economics, University of Padang.

6. Online shop social media does not have an influence on consumer behavior. This suggests that the contribution of social media to online shop consumer behavior students of Faculty of Economics, University of Padang.

7. Lifestyle has an influence on consumer behavior. Forms of lifestyle variables to influence consumer behavior is positive. This shows that the better the lifestyle of a student, the better the consumer behavior students of Faculty of Economics, University of Padang.

\section{References}

Angra Melina, Saftia Wulandari. (2018). Pengaruh Literasi Ekonomi Dan Gaya Hidup Terhadap Perilaku Konsumtif Mahasiswi Pendidikan Ekonomi STKIP." 141-52.

Astuti, Rika Pristian Fitri. 2014. "Pengaruh Status Sosial Ekonomi Orang Tua, Literasi Ekonomi Dan Life Style Terhadap Perilaku Konsumsi Mahasiswa Jurusan Pendidikan Ekonomi Ikip Pgri Bojonegoro." : 49-58.

Boyd Thomas, Jane, and How Lee Okleshen Peters. (2009). "Silver Seniors: Exploring the Self-Concept, Lifestyles, and Apparel Consumption of Women Over Age 65." International Journal of Retail $\mathcal{E}$ Distribution Management 37 (12): 1018-40.

Edwar, Nikmatul Fitriyah dan Muhammad. (2013). "Pengaruh Kelompok Acuan Dan Keluarga Terhadap Keputusan Pembelian Batik Tulis Jetis Pada Toko Amri Jaya Sidoarjo."(1): 121-134.

Grover, Aditi et al. 2011. "From Use to Abuse: Everyday When Morph Into Consumption Behaviors consumptive Addictive Behaviors." Journal of Research for Consumers: 1-7.

Hartiyani Sadu Budanti, Mintasih Indriayu \& Muhammad Sabandi. "Pengaruh Lingkungan Sosial Dan Gaya Hidup Terhadap Perilaku Konsumsi Mahasiswa Program Studi Pendidikan Ekonomi FKIP UNS." : 1-14.

Hidayat, A, and Chandra Kurniawan. (2016). "Pengaruh Konsep Diri Dan Kepercayaan Diri Terhadap Perilaku Konsumtif Pembelian Gadget Pada Mahasiswa Fakultas Hukum Non Reguler Universitas Islam Riau." An-Nafs 10(01): 1-10.

Kaharu, Debora, and Anindhyta Budiarti. (2016). "Pengaruh Gaya Hidup, Promosi, Dan Kualitas Produk Terhadap Keputusan Pembelian Pada Cosmic." Jurnal Ilmu dan Riset Manajemen, ISSN : 2461-0593 5(3): 1-24.

Liang, Austin Rong Da. (2014). "Enthusiastically Consuming Organic Food: An Analysis of the Online Organic Food Purchasing Behaviors of Consumers with Different Food-Related Lifestyles." Internet Research 24 (5): 587-607.

Lin, Long®Yi, and Yeun®Wen Chen. 2009. "A Study on the Influence of Intentions on Repurchase Purchase Decisions: The Moderating Effects of Reference Groups and Perceived Risks."

Tourism Review 64 (3): 28-48.

Lubis, Arlina Nurbaity, and University of North Sumatra. (2018). "Evaluating The Customer Preferences Of Online Shopping: Demographic Factors And Online Shop Application Issue." 17 (2): $1-13$.

Miranda, By Sofia, Supervisor Evawani, Elysa Lubis, and M Si. (2017). "Effect of Instagram For Media Online Shopping Consumer Behavior Fashion Against Student Faculty of Social and Political Science, University of Riau." 4 (1): 1-15.

Mittal, Banwari. 2015. "Self-Concept Clarity: Exploring Its Role in Consumer Behavior." Journal of Economic Psychology 46: 98-110. http://dx.doi.org/10.1016/j.joep.2014.11.003.

Murwanti, Dwi. 2015. "Effects of Self-Concept, Peers and Contemporary Culture Consumer Behavior Students Against Smp Negeri 41 Surabaya." 5 (1): 38-51.

Pandey, Shweta, and Deepak Chawla. 2014. "E-Lifestyles of Indian Online Shoppers: A Scale 
Validation." Journal of Retailing and Consumer Services 21 (6): 1068-74. http://dx.doi.org/10.1016/j.jretconser.2014.06.012.

Paulina Guerrero, Maja Steen Møller, Anton Stahl Olafsson and Bernhard Snizek. 2016. "Revealing Cultural Ecosystem Services through Instagram Images: The Potential of Social Media volunteered Geographic Information for Urban Green Infrastructure Planning and Governance." 1 (2): 1-17.

Pontania, Almira Rizki. 2016. "The Hedonist Lifestyle Students of Sma Negeri 4 With Lifestyle Hedonist.": 115-124.

Idham Putra Perdana, Endah Mujiasih. 2017. "The Relationship Between Conformity Peers With Consumer Buying Behavior Clothes On Force Student 2016 Diponegoro University Psychology Department." 6 (No. 4): 195-208.

Rusich, E, A. (2008). Department Of Psychology Loyola University New Orleans: The Relationship beetween Conformity And Consumer Purchasing Decision. Journal of Consumer Research. Published by Missouri: Missouri Western State University.

Roe, David, and Johan Bruwer. 2017. "Self-Concept, Product Involvement and Consumption Occasions: Exploring Fine Wine Consumer Behavior." British Food Journal 119 (6): 1362-77.

Way, Aprilliyana Dwi, Rifai Strong Widiyanto, and Nursery Alfaridi Nasution. 2016. "Analysis of The Effect of Technology Improvement Towards Human Lifestyle (Case Study: Online Motorcycle taxi).": 863-77.

Salazar, Helen Arce, Leon Oerlemans, and Saskia Van Stroe-Biezen. 2013. "Social Influence on Sustainable Consumption: Evidence from a Behavioral Experiment." International Journal of Consumer Studies 37 (2): 172-80.

Stephen, Andrew T. 2008. "The Role Of Digital And Social Media Marketing In Consumer Behavior [The Role Of Digital And Social Media Marketing In Consumer Behavior]." Evolution: 1-14.

Sukarno, Iwan, Hiroshi Matsumoto, and Lusi Susanti. 2017. "Urban Climate Household Lifestyle Effect on Residential Electrical Energy Consumption in Indonesia: On-Site Measurement Methods." Urban Climate. http://dx.doi.org/10.1016/j.uclim.2017.02.008.

Syahfitri, Lisfah Asbi. 2017. "Pengaruh Kelompok Referensi Terhadap Gaya Hidup Dan Keputusan Pembelian Hijab Rabbani Kota Pekanbaru." ぎょうせい: 3.

Thomas, Veronica L. 2015. "Hidden Consumption Behavior: An Alternative Response to Social Group Influence." Emerald Insight 10 (4): 781-800.

Wibowo, Bambang Setia. 2018. "Pengaruh Instagram Online Store, Konformitas Dan Iklan Televisi Terhadap Perilaku Konsumtif Serta Dampaknya Terhadap Gaya Hidup Hedonis Mahasiswa." 9(1): 1-12. 